\title{
PENINGKATAN KEMAMPUAN MENULIS KREATIF PUISI MELALUI MEDIA ALAM SEKITAR PADA SISWA KELAS XII SMK NEGERI 7 TAKALAR KABUPATEN TAKALAR
}

\author{
Andi Syamsul Alam
}

\begin{abstract}
Objective That's review describes the ability of a creative writing poetry through Natural Media About AT Class XII SMK Negeri 7 Takalar Takalar. Singer study using a Class Action Research Procedure CYCLE WITH prayer. Research data collection techniques using test engineering and non engineering test, which consists differences observations, journals, and interviews. Data analysis using qualitative and quantitative approaches. Results concluded that the ability to write poetry I Class XII TKJ SMK Negeri 7 Takalar taxable income following the write poems Learning through Natural Media Neighborhood increased. Increased singer looks From the average value changes from cycle I to cycle II. I CYCLE IN TIN findings class average of 58.28. ON CYCLE II TIN findings of an average of 90.43. It Singer showed an increase from cycle I to cycle II amounted to $32.15 \%$. Based on non-test data can be known of the change of Conduct Toward Students learn, positive. THE CYCLE I look Enthusiastic Students Still Not Learning hearts follow. DIFFERENT IN CYCLE II, Students Active Learning follows the hearts and spirit.
\end{abstract}

Keywords: Poetry Writing Ability, Natural Media Neighborhood

\section{ABSTRAK}

Tujuan penelitian yaitu untuk mendeskripsikan kemampuan menulis kreatif puisi melalui media alam sekitar pada siswa kelas XII SMK Negeri 7 Takalar Kabupaten Takalar.

Penelitian ini menggunakan prosedur penelitian tindakan kelas dengan dua siklus. Teknik pengumpulan data penelitian menggunakan teknik tes dan teknik non tes, yang terdiri atas observasi, jurnal, dan wawancara. Analisis data menggunakan pendekatan kualitatif dan pendekatan kuantitatif.

Hasil penelitian disimpulkan bahwa kemampuan menulis puisi siswa kelas XII TKJ I SMK Negeri 7 Takalar setelah mengikuti pembelajaran menulis puisi melalui media alam sekitar mengalami peningkatan. Peningkatan ini terlihat dari perubahan nilai rata-rata dari siklus I ke siklus II. Pada siklus I diperoleh hasil rata-rata kelas sebesar 58,28. Pada siklus II diperoleh hasil rata-rata sebesar 90,43. Hal ini menunjukkan peningkatan dari siklus I ke siklus II sebesar $32,15 \%$. Berdasarkan data non tes dapat diketahui adanya perubahan perilaku belajar siswa ke arah positif. Pada siklus I siswa masih belum terlihat antusias dalam mengikuti pembelajaran. Berbeda pada siklus II, siswa aktif dan semangat dalam mengikuti pembelajaran.

Kata kunci: Kemampuan Menulis Puisi, Media Alam Sekitar.

I. PENDAHULUAN

Latar Belakang
Menulis kreatif puisi merupakan salah satu keterampilan bidang apresiasi sastra yang harus dikuasai oleh siswa SMK. Di dalam kurikulum Bahasa Indonesia, materi menulis kreatif puisi terdapat pada pembelajaran yang 
diajarkan di kelas XII yakni mengungkapkan pikiran dan perasaan melalui kegiatan menulis kreatif puisi. Akan tetapi, pada kenyataannya pembelajaran menulis di sekolah masih banyak mengalami kendala dan cenderung dihindari. Pembelajaran menulis puisi di SMK dilakukan dengan tujuan, meningkatkan kemampuan siswa dalam mengapresiasi karya sastra.

Hal itu berkaitan erat dengan latihan mempertajam perasaan, penalaran, dan daya khayal, serta kepekaan terhadap masyarakat, budaya, dan lingkungan hidup. Seperti yang diungkapkan Pradopo (1997) bahwa puisi adalah ekspresi kreatif, yaitu ekspresi dari aktivitas jiwa yang memusatkan kesankesan atau (kondisi). Kesan-kesan dapat diperoleh melalui pengalaman dan lingkungan. Oleh karena itu, anggapan bahwa menulis puisi sebagai aktivitas yang sulit, khususnya siswa SMK karena rata-rata masih berusia 15-16 tahun. Anak pada usia tersebut sudah dapat berfikir refleksif dan menyatakan operasi mentalnya dengan simbol-simbol. Artinya mereka bisa mengungkapkan pikiran dan perasaan yang ada pada dirinya dalam bentuk puisi. Namun, kenyataannya di lapangan menunjukkan bahwa banyak siswa yang belum mampu melaksanakan kegiatan tersebut secara optimal. Rendahnya kemampuan siswa dalam menulis tersebut disebabkan oleh kurang efektifnya pembelajaran yang diciptakan guru. Ketidakefektifnya itu disebabkan oleh kurang tepatnya strategi yang diterapkan guru dalam pembelajaran. Strategi yang dipakai guru tidak dapat mengembangkan potensipotensi yang ada pada diri siswa agar secara leluasa dapat mengekspresikan perasaannya.

Melalui pembelajaran sastra menulis kreatif puisi ini, anak diharapkan menjadi warga yang menjunjung tinggi nilai-nilai moral yang luhur. Maka dari itu alangkah baiknya pengajaran bahasa Indonesia harus kembali kepada kedudukan yang sebenarnya yaitu membaca, menulis, berbicara, mendengarkan dan mengapresiasi sastra yang sesungguhnya. Guru harus menghindari pembelajaran yang berisi pengetahuan bahasa Indonesia tetapi apa yang diajarkan seharusnya hal-hal nyata dan dekat dengan kebutuhan berbahasa Indonesia siswa.

Model pembelajaran yang tepat untuk menulis puisi dengan menggunakan media lingkungan ialah model kontekstual dengan teknik-teknik inkuiri, tanya-jawab, konstruksionisme, pemodelan, dan kooperatif.

\section{KAJIAN PUSTAKA}

Menulis adalah suatu proses
menyusun, mengkomunikasikan makna dalam tataran ganda bersifat interaktif dan diarahkan untuk mencapai tujuan tertentu dengan menggunakan suatu sistem yang konvensional yang dapat dilihat atau dibaca (Tarigan, 1993).

Potensi alam yang asri itu dapat dijadikan lahan dalam pembelajaran sastra yang menarik, dan dapat dijadikan media pembelajaran sastra yang efektif. Disamping itu sesuai dengan konsep pembelajaran, belajar sesuai dengan kenyataan yang ada dilapangan itu akan lebih mengenal bila dibandingkan dengan sesuatu yang abstrak.

Lingkungan sekolah sebetulnya merupakan media yang potensial untuk pembelajaran sastra dengan mengajak anak-anak duduk dihalaman sekolah siswa dibiarkan berekspresi untuk menulis sesuai dengan apa yang dilihat, didengar, dan dirasakan berdasarkan pemikiran masing-masing.

Sampai saat ini menulis puisi belum banyak diminati para siswa, masih banyak yang beranggapan bahwa untuk 
dapat menulis puisi seseorang harus mempunyai bakat dulu, itu terlihat dari sifat siswa yang kurang memperhatikan guru saat mengajar, mengobrol dengan teman sebangku, mengantuk dalam kelas, menggaruk-garuk kepala dan yang paling signifikan ialah hasil nilai siswa saat diadakannya perlombaan menulis puisi antar kelas, dan setiap ditanya siswa pasti menjawab "gak hobi", pandangan seperti ini tidak semua benar, memang bakat itu merupakan salah satu faktor pendukung bagi seseorang untuk menyukai bidang tertentu, tetapi tanpa latihan bakat itu tidak akan ada.

Dengan demikian para guru mata pelajaran selalu dituntut untuk dapat menguasai materi yang akan disampaikan, materi atau bahan ajar yang mampu membimbing siswa untuk meningkatkan kemampuan menulis. Puisi siswa yang merupakan suatu usaha membuat tulisan atau karya dalam bidang puisi, didalam puisi siswa harus memenuhi dua kriteria yaitu keterbacaan dan kesesuaian.

Penggunaan media pengajaran sangat diperlukan dalam kaitannya dengan peningkatan mutu pendidikan khususnya dalam pembelajaran menulis puisi. Media yang tepat digunakan adalah melalui media alam sekitar. Alam berarti gambaran alam yang ada disekitar kita yang banyak menyajikan beragam keindahan, kemistikan dan perubahan yang semuanya mampu memberikan inspirasi dan mampu sebagai alat ukur untuk mengembangkan daya tingkat imajinasi yang tinggi. Sedangkan fenomena adalah hal-hal yang terjadi di alam semesta yang sanggup menggugah hati nurani kita untuk bisa memberikan respon terhadap apa yang kita lihat oleh panca indera, baik itu berupa kejadian yang menyedihkan maupun kegembiraan yang semuanya itu tidak terlepas dari kodrat kita sebagai manusia biasa yang pastinya ikut merasakan segala sesuatu yang terjadi di alam semesta. Begitupun dengan alam bahwa segala sesuatu yang ada dilangit dan bumi yang menjadi objek dalam penulisan sebuah puisi, yang di dalam pengucapannya mengandung sebuah unsur kiasan yang akhirnya mampu melahirkan makna baru yang nantinya akan memperindah puisi melalui sebuah media yaitu alam sendiri.

\section{METODE PENELITIAN}

Penelitian ini yang akan dilakukan adalah penelitian tindakan kelas (class room action researc). Menurut Arikunto (2007), penelitian tindakan kelas adalah suatu pencermatan terhadap kegiatan belajar berupa sebuah tindakan yang sengaja dimunculkan dan terjadi dalam sebuah kelas secara bersamaan, juga sebagai proses pengkajian masalah pembelajaran didalam kelas melalui refleksi dalam upaya untuk memecahkan masalah tersebut dengan cara melakukan berbagai tindakan yang terencana dalam situasi nyata serta menganalisis setiap pengaruh dari perlakuan tersebut. Untuk memperoleh data dalam penelitian ini digunakan instrumen tes dan non tes. Instrumen tes digunakan untuk mengetahui kemampuan siswa dalam menulis puisi. Adapun instrumen non tes digunakan untuk mengetahui perubahan tingkah laku siswa yang berupa lembar observasi, jurnal dan wawancara. Teknik analisis data yang digunakan dalam penelitian ini adalah teknik kualitatif dan teknik kuantitatif.

Teknik kualitatif digunakan untuk menganalisis data-data yang bersifat kualitatif yang diperoleh dari data non tes observasi, wawancara, dan catatan harian. Sedangkan teknik kuantitatif digunakan untuk menganalisis data kuantitatif. Data tersebut diperoleh dari hasil puisi siswa pada siklus I dan siklus II. Hasil penghitungan pada siklus I dan siklus II akan menghasilkan presentase 
peningkatan keterampilan menulis puisi pada siswa melalui media alam sekitar.

\section{HASIL PENELITIAN}

Hasil Penelitian tindakan kelas ini diperoleh dari hasil tes dan non tes selama penelitian berlangsung. Hasil tes prasiklus menunjukkan keterangan mengenai pembelajaran menulis puisi sebelum diadakan penelitian, sedangkan hasil tes siklus I dan siklus II menunjukkan keterangan mengenai pembelajaran menulis puisi setelah diadakan penelitian.

Hasil tes berupa keterampilan menulis melalui media alam sekitar disajikan dalam bentuk kuantitatif, sedangkan hasil penelitian perubahan tingkah laku yang berupa non tes disajikan dalam bentuk deskripsi data kualitatif. Hasil non tes berupa hasil observasi, jurnal, dan wawancara.

\section{Hasil Penelitian pada Siklus I}

Pembelajaran menulis puisi suklus I merupakan tindakan awal penelitian menulis puisi melalui media alam sekitar. Tindakan yang dilakukan pada siklus I merupakan tindakan sebagai upaya memperbaiki dan memecahkan masalah yang muncul ketika peneliti melakukan

Tabel 4.1

Nilai yang diperoleh Siswa Kelas XII TKJ I dalam Menulis Puisi Melalui Media Alam Sekitar pada Siklus I

\begin{tabular}{|c|c|c|c|c|c|c|c|}
\hline \multirow[t]{3}{*}{ No } & \multirow{3}{*}{$\begin{array}{l}\text { Nama } \\
\text { Siswa }\end{array}$} & \multicolumn{4}{|c|}{ Aspek Penilaian } & \multirow{3}{*}{$\begin{array}{l}\text { Nilai } \\
\text { Siswa }\end{array}$} & \multirow{3}{*}{$\begin{array}{c}\text { Kategori } \\
\text { Nilai }\end{array}$} \\
\hline & & & Kesesuaian & & & & \\
\hline & & Judul & $\begin{array}{c}\text { Isi dengan } \\
\text { Tema }\end{array}$ & Diksi & Tipografi & & \\
\hline 1 & $\begin{array}{l}\text { Anggi } \\
\text { Sastrawati }\end{array}$ & 12 & 6 & 16 & 15 & 49 & Kurang \\
\hline 2 & $\begin{array}{l}\text { Hardiyant } \\
\mathrm{y}\end{array}$ & 6 & 12 & 16 & 10 & 44 & Kurang \\
\hline 3 & Irmayanti & 18 & 12 & 8 & 10 & 48 & Kurang \\
\hline
\end{tabular}

observasi. Proses inti pembelajaran menulis puisi melalui media alam sekitar diawali dengan cara guru dan siswa bertanya jawab mengenai materi pembelajaran menulis puisi.

Pada tahap ini siswa masih pasif dan guru lebih sering menerangkan materi. Setelah semua materi selesai guru menyuruh siswa membayangkan pemandangan alam di sekitar mereka. Kemudian menuangkan apa yang ada didalam pikiran mereka dalam bentuk puisi.

Pada hasil penelitian siklus I dibahas hasil tes dan nontes. Data tes diperoleh dari hasil keterampilan menulis puisi pada siswa kelas XII TKJ I SMK Negeri 7 Takalar melalui media alam sekitar. Data non tes diperoleh dari hasil observasi, jurnal, dan wawancara.

\section{a. Hasil Tes pada Siklus I}

Hasil tes siklus I merupakan hasil keterampilan siswa dalam menulis puisi melalui media alam sekitar. Siswa yang mengikuti tes keterampilan menulis puisi berjumlah 21 siswa. Rata-rata hasil tes siswa dalam menulis puisi pada siklus I secara umum dapat digambarkan seperti tabel di bawah ini: 


\begin{tabular}{|c|c|c|c|c|c|c|c|}
\hline 4 & $\begin{array}{l}\text { Nur } \\
\text { Alifka } \\
\text { Kadir }\end{array}$ & 12 & 18 & 16 & 10 & 56 & Cukup \\
\hline 5 & Nur Fajri & 6 & 18 & 8 & 10 & 42 & Kurang \\
\hline 6 & Rahmi & 18 & 12 & 24 & 15 & 69 & Cukup \\
\hline 7 & Sari Nita & 6 & 18 & 24 & 10 & 58 & Cukup \\
\hline 8 & Sudarmi & 12 & 12 & 16 & 10 & 50 & Cukup \\
\hline 9 & Sunarti M & 18 & 12 & 24 & 15 & 69 & Cukup \\
\hline 10 & Suriyanti & 18 & 18 & 16 & 10 & 62 & Cukup \\
\hline 11 & $\begin{array}{l}\text { Teti } \\
\text { Armita }\end{array}$ & 12 & 12 & 16 & 15 & 55 & Cukup \\
\hline 12 & $\begin{array}{l}\text { Yola } \\
\text { Indah } \\
\text { Pratiwi }\end{array}$ & 18 & 18 & 16 & 10 & 62 & Cukup \\
\hline 13 & Yunita & 18 & 18 & 24 & 15 & 75 & Baik \\
\hline 14 & $\begin{array}{l}\text { Aan } \\
\text { Kurniadi }\end{array}$ & 12 & 18 & 16 & 10 & 56 & Cukup \\
\hline 15 & $\begin{array}{l}\text { Muh } \\
\text { Danial }\end{array}$ & 18 & 12 & 16 & 15 & 61 & Cukup \\
\hline 16 & Suharmin & 18 & 18 & 16 & 10 & 62 & Cukup \\
\hline 17 & Yulianto & 12 & 12 & 24 & 10 & 58 & Cukup \\
\hline 18 & Zulkifli & 18 & 12 & 24 & 15 & 69 & Cukup \\
\hline 19 & $\begin{array}{l}\text { Dadang } \\
\text { Alfian }\end{array}$ & 12 & 18 & 16 & 15 & 61 & Cukup \\
\hline 20 & $\begin{array}{l}\text { Reski } \\
\text { Anria } \\
\text { Nasir }\end{array}$ & 12 & 18 & 16 & 10 & 56 & Cukup \\
\hline 21 & Ismail & 18 & 12 & 24 & 10 & 64 & Cukup \\
\hline & Jumlah & 294 & 306 & 376 & 250 & 1.226 & \\
\hline \multicolumn{2}{|c|}{ Rata-rata } & 14 & 14,57 & $\begin{array}{c}17,9 \\
0\end{array}$ & 11,90 & 58,38 & Cukup \\
\hline
\end{tabular}

Untuk lebih jelasnya, nilai yang diperoleh siswa dalam menulis puisi melalui media alam sekitar pada siklus I adalah sebagai berikut:

Tabel 4.2

Hasil Tes Menulis Puisi Siswa Kelas XII TKJ I pada Siklus 1

\begin{tabular}{clccccc}
\hline No & Kategori & Nilai & Frekuensi & Jumlah Nilai & $\%$ & $\begin{array}{c}\text { Rata- } \\
\text { rata }\end{array}$ \\
\hline 1 & Sangat Baik & $90-100$ & 0 & 0 & 0 & \\
\hline 2 & Baik & $70-89$ & 1 & 75 & 4,76 & \\
\hline
\end{tabular}




\begin{tabular}{ccccccc}
\hline 3 & Cukup & $50-69$ & 16 & 968 & 76,19 & \multirow{5}{*}{$\mathbf{5 8 , 3 8}$} \\
\cline { 1 - 5 } 4 & Kurang & $0-49$ & 4 & 183 & 19,05 & \\
\cline { 1 - 5 } & Jumlah & & $\mathbf{2 1}$ & $\mathbf{1 . 2 2 6}$ & $\mathbf{1 0 0}$ & \\
\hline
\end{tabular}

Sumber: Data diolah

Berdasarkan pada tabel 4.2 mengenai hasil tes menulis puisi siswa kelas XII TKJ I pada siklus 1 dapat dilihat bahwa dari total 21 siswa pada kelas XII TKJ I tidak ada siswa yang mendapatkan nilai dalam kategori sangat baik atau sebesar 0\%. Siswa yang mendapatkan nilai dalam kategori baik sebanyak 1 siswa atau sekitar $4,76 \%$ dan siswa yang mendapatkan nilai dalam kategori cukup sebanyak 16 siswa atau sekitar 76,19\% dan siswa yang mendapatkan nilai dalam kategori kurang sebanyak 4 siswa atau sekitar 19,05\%. Namun, dari keempat aspek tersebut belum mencapai ketuntasan. Hasil keseluruhan dari keempat aspek tersebut yaitu rata-rata 58,38. Secara umum belum mencapai ketuntasan rata-rata kelas yaitu 75,00.

\section{b. Hasil Non Tes Siklus I}

Pada siklus I, data non tes diperoleh dari hasil observasi, jurnal, dan wawancara. Hasil non tes selengkapnya akan dijelaskan pada uraian berikut ini:

\section{1) Hasil Observasi Siklus I}

Observasi dilakukan selama proses pembelajaran menulis puisi. Pengambilan data ini dilakukan dengan tujuan untuk mengetahui respon siswa melalui perilaku mereka selama pembelajaran menulis puisi melalui media alam sekitar. Observasi dilakukan oleh peneliti dan dibantu oleh satu seorang rekan peneliti. Berdasarkan hasil pengamatan atau observasi peneliti pada saat pembelajaran, secara keseluruhan perilaku siswa dalam pembelajaran menulis puisi sudah baik. Hal tersebut dapat dilihat dari tabel 4.3 diawah ini:

Tabel 4.3

Hasil Observasi Siswa pada Siklus I

Aspek Pengamatan

F (\%)

\begin{tabular}{llll}
\hline a. Siswa mendengarkan penjelasan guru dengan penuh perhatian & 17 & 80,95 \\
b. Siswa aktif mencatat penjelasan guru & 16 & 76,19 \\
c. Siswa dapat bekerja sama dengan temannya & 15 & 71,42 \\
d. Siswa aktif bertanya kepada guru & 10 & 47,62 \\
e. Siswa aktif menjawab pertanyaan atau memberikan tanggapan & 12 & 57,14 \\
f. Siswa bersungguh-sungguh dalam mengerjakan tugas & 16 & 76,19 \\
\hline
\end{tabular}

Berdasarkan data pada tabel 4.3 di atas mengenai hasil observasi pada siklus I dapat diketahui bahwa dari 21 siswa pada kelas TKJ I sebanyak 17 siswa atau sekitar 80,95\% siswa mendengarkan penjelasan guru dengan penuh perhatian pada saat pembelajaran menulis puisi. Pada saat guru memberikan waktu untuk mencatat penjelasan guru, sebanyak 16 siswa atau sekitar 76,19\% dari jumlah keseluruhan siswa aktif mencatat penjelasan guru sedangkan beberapa siswa terlihat kurang antusias mencatat. Guru menegur siswa yang berbicara sendiri. Saat guru menegur, beberapa siswa mengaku sudah mencatat namun saat guru melihat catatan siswa ternyata catatannya tidak lengkap, sehingga guru 
menyuruh siswa melengkapi catatannya. Siswa yang dapat bekerja sama dengan temannya sebanyak 15 siswa atau sekitar $71,42 \%$. Siswa yang aktif bertanya sebanyak 10 siswa atau sekitar $47,62 \%$ sedangkan siswa yang aktif menjawab pertanyaan atau memberikan tanggapan sebanyak 12 siswa atau sekitar $57,14 \%$ serta siswa yang bersungguh-sungguh dalam mengerjakan tugas sebanyak 16 atau sekitar 76,19\%.

\section{2) Hasil Jurnal Siklus I}

Jurnal yang digunakan pada tindakan siklus I ini ada dua macam, yaitu jurnal siswa dan jurnal guru. Kedua hasil jurnal dalam tindakan siklus I diuraikan sebagai berikut.

\section{a) Jurnal Siswa pada Siklus I}

Pengisian jurnal dilakukan oleh semua siswa kelas TKJ I SMK Negeri 7 Takalar. Jurnal tersebut diisi pada akhir pembelajaran menulis puisi. Tujuan dari pengisian jurnal siswa adalah untuk mengetahui respon, pesan maupun kesan siswa terhadap pembelajaran menulis puisi melalui media alam sekitar.

Hal-hal yang diungkap dalam jurnal siswa siklus I didik meliputi: (1) perasaan siswa selama mengikuti pembelajaran menulis puisi melalui media alam sekitar, (2) kesulitan yang dialami siswa selama mengikuti pembelajaran menulis puisi melalui media alam sekitar, (3) pesan dan kesan siswa setelah mengikuti pembelajaran menulis puisi melalui media alam sekitar, (4) tanggapan mengenai media dan metode yang digunakan dalam pembelajaran menulis puisi melalui media, dan (5) suasana kelas saat pembelajaran pembelajaran menulis puisi melalui media alam sekitar.

Dari hasil jurnal siklus I dapat diketahui bahwa 18 siswa atau $85,71 \%$ menganggap langkah menulis puisi yang diajarkan guru membuat siswa semakin mudah menulis puisi. Sebagian besar siswa tertarik dan antusias pada saat kegiatan belajar namun ada siswa yang merasa kesulitan karena belum pernah menulis puisi sama sekali. Hal tersebut bisa diatasi dengan adanya media alam sekitar yang merangsang mereka untuk menulis puisi.

Menurut sebagian besar siswa dengan penerapan media alam sekitar tersebut melatih mereka untuk berfikir secara individu meskipun dalam kondisi berkelompok. Siswa dapat berlatih apa artinya bekerja sama dengan teman satu kelompok dan saling memberi tahu yang tidak tahu menjadi tahu. Selain itu dengan adanya media alam sekitar mereka lebih mudah memahami pembelajaran, siswa juga dapat belajar membuat puisi yang baik.

Menurut siswa penggunaan media alam sekitar juga lebih menyenangkan dan tidak membosankan karena berbeda dengan kegiatan pembelajaran yang biasanya. Suasananya pembelajaran menurut mereka cukup kondusif meskipun pada awal pembelajaran sedikit gaduh. Meskipun demikian, ada beberapa siswa yang masih mengalami kesulitan dalam menentukan judul yang menarik, serta merangkai kata-kata menjadi sebuah puisi. Dari data jurnal siswa dapat disimpulkan bahwa sebagian besar siswa tertarik dan senang mengikuti pembelajaran menulis puisi melalui media media alam sekitar, namun masih ada kesulitan dihadapi oleh siswa selama proses pembelajaran. Oleh karena itu, masih diperlukan perbaikan untuk mengatasi kendala dan kesulitan yang dihadapi siswa.

\section{b) Jurnal Guru pada Siklus I}

Jurnal guru berisi seluruh kejadian yang dilihat dan dirasakan oleh guru selama proses pembelajaran berlangsung, 
jurnal ini diisi oleh guru yang menyampaikan materi pelajaran, dalam hal ini adalah peneliti sendiri. Hal-hal yang terdapat dalam jurnal guru yaitu: (1) bagaimana tanggapan siswa terhadap materi pembelajaran menulis puisi melalui media alam sekitar (2) bagaimana tanggapan siswa terhadap pembelajaran menulis puisi melalui media, (3) bagaimana tanggapan siswa terhadap media yang digunakan dalam pembelajaran menulis puisi melalui media alam sekitar, (4) bagaimana tanggapan siswa terhadap media yang digunakan dalam pembelajaran menulis puisi melalaui media alam sekitar, dan (5) bagaimana situasi dan suasana kelas saat berlangsungnya pembelajaran menulis puisi melalui media alam sekitar.

Berdasarkan hasil jurnal guru pada siklus I, dapat disimpulkan bahwa pembelajaran menulis puisi melalui media alam sekitar berjalan cukup baik dan lancar. Berdasarkan pengamatan guru selama proses pembelajaran, sebagian besar siswa sudah lebih baik memahami materi yang disampaikan oleh guru. Dengan adanya media yang diterapkan oleh guru siswa lebih bersemangat dalam belajar. Walaupun sebagian siswa juga sudah bisa memahami tugas yang diberikan dan mengerjakan tugas dengan baik tetapi ada pula beberapa siswa yang mengerjakan tugas dengan malas-malasan dan kurang serius. Situasi dan suasana kelas saat pembelajaran berlangsung cukup tenang walaupun saat awal pembelajaran cukup gaduh.

\section{c) Hasil Wawancara Siswa pada Siklus 1}

Kegiatan wawancara dilakukan setelah selesai pembelajaran pada siklus I. Sasaran wawancara difokuskan pada tiga siswa, yaitu satu siswa yang mendapat nilai tertinggi, satu siswa yang mendapat nilai sedang/cukup, dan satu siswa yang mendapat nilai rendah/kurang. Tujuan peneliti melakukan wawancara pada siklus I ini adalah untuk mengetahui tanggapan atau sikap siswa terhadap pembelajaran menulis puisi melalui media alam sekitar.

Wawancara ini terdiri atas delapan pertanyaan, yaitu: (1) Apakah siswa tertarik dengan pembelajaran menulis puisi, (2) Bagimana suasana pembelajaran menulis puisi melalui media alam sekitar, (3) Apakah siswa memahami penjelasan guru dalam pembelajaran menulis puisi,

Bagaimana penjelasan guru dalam pembelajaran menulis puisi, (5) Bagaimana pendapatmu terhadap media yang digunakan dalam pembelajaran menulis puisi, (6) Kesulitan apa yang kamu hadapi selama kegiatan pembelajaran menulis puisi tadi, dan (7) Bagaimana pendapatmu tentang kegiatan pembelajaran menulis puisi melalui media alam sekitar.

Berdasarkan wawancara yang dilakukan terhadap tiga siswa tersebut dapat disimpulkan bahwa secara keseluruhan siswa senang dan tertarik dengan pembelajaran menulis puisi. siswa yang mendapat nilai tinggi mengungkapkan ketertarikannya karena media yang digunakan mempermudah dalam pembuatan puisi. Siswa yang mendapat nilai sedang mengungkapkan bahwa dia sangat senang belajar menulis puisi dikarenakan penjelasan guru yang mudah diterima dan dipahami. Dan menurut siswa yang mendapat nilai rendah juga mengungkapkan ketertarikannya dalam menulis puisi melalui media alam sekitar tersebut meskipun terkadang merasa kesulitan mengungkapkan ide-ide.

Secara keseluruhan siswa merasa terbantu karena dapat mengetahui cara membuat puisi dengan mudah dan benar 
karena medianya sangat bagus. Selain itu, menurut siswa penyampaian materi dari guru cukup jelas dan mudah dipahami. Mereka juga merasa pembelajarannya terkesan santai tapi tetap serius sehingga membuat belajar menyenangkan.

\section{3) Refleksi pada Siklus 1}

Pembelajaran menulis puisi pada siklus I ini merupakan upaya untuk memperbaiki dan memecahkan masalah yang dihadapi pada prasiklus. Namun, setelah dilakukan pembelajaran menulis puisi melalui media alam sekitar pada siklus I, guru merasa belum puas karena masih adanya permasalahanpermasalahan yang menyebabkan hasil pembelajaran kurang maksimal. Nilai rata-rata yang dicapai siswa pada siklus I baru mencapai 58,28 dengan kategori cukup, dan belum mencapai target yang ditentukan yaitu 75,00. Pada pembelajaran siklus I ini masih banyak kesulitan-kesulitan yang ditemui siswa. Kesulitan tersebut berkenaan dengan aspek diksi atau pemilihan kata dan kesulitan dalam merangkai kata-kata dalam menulis puisi. Kesulitan siswa ini terjadi karena jarangnya siswa berlatih menulis puisi dan tidak adanya teknik, metode, model, dan media yang menarik bagi siswa sehingga mereka kesulitan mengungkapkan ide.

Berdasarkan hasil observasi, jurnal, dan wawancara dapat diketahui perilaku siswa tergolong cukup baik, walaupun ada beberapa siswa yang masih tidak memperhatikan pembelajaran. Pada siklus I siswa merasa lebih mudah untuk memahami materi menulis puisi. Menurut mereka pembelajaran menulis puisi melalui media alam sekitar menyenangkan karena mereka bisa bekerja secara berkelompok serta dapat memudahkan mereka menulis puisi.

Meskipun demikian, beberapa siswa masih terlihat kurang antusias dalam mengikuti pembelajaran menulis puisi melalui media alam sekitar. Pada saat pembelajaran berlangsung, masih ada siswa yang terlihat pasif dan tidak memerhatikan pembelajaran ketika guru menjelaskan materi. Guna mencapai pembelajaran yang sesuai dengan apa yang diharapkan oleh guru, maka kesulitan-kesulitan tersebut kiranya harus dicari jalan keluarnya untuk kemudian diterapkan pada pembelajaran selanjutnya. Hal-hal yang dilakukan guru berkenaan dengan upaya perbaikan untuk kemudian diterapkan pada pembelajaran selanjutnya.

Dengan demikian, tindakan siklus II perlu segera dilakukan dengan harapan supaya prestasi siswa lebih meningkat dalam menulis puisi. Pada siklus II halhal yang dilakukan guru berkenaan dengan upaya perbaikan untuk kemudian diterapkan pada pembelajaran selanjutnya, yaitu memperbaiki rencana pelaksanaan pembelajaran, sehingga guru lebih memberikan motivasi pada siswa dengan membuat pembelajaran menjadi lebih santai sehingga siswa merasa senang untuk mengikuti pembelajaran, guru memotivasi dan membimbing siswa menentukan objek atas apa yang dilihat dari alam sekitar tersebut agar mampu memilih kata yang tepat atas puisi yang telah ditentukan temanya serta mampu merangkai kata-kata tersebut, guru menjelaskan kesalahan-kesalahan yang dilakukan siswa pada saat menulis puisi sehingga siswa lebih paham dan dapat memperbaiki kesalahannnya, dan memberi materi yang lebih lengkap lagi dibandingkan dengan siklus I. Perbaikanperbaikan ini diharapkan dapat meningkatkan prestasi siswa dalam menulis puisi pada siklus II.

\section{Hasil Penelitian pada Siklus II}

Penelitian siklus II dilaksanakan sebagai perbaikan siklus I karena pada 
siklus I kemampuan menulis puisi belum mencapai target yang diharapkan. Penelitian siklus II dilaksanakan dengan rencana dan persiapan yang lebih matang lagi dengan mempertahankan hal yang sudah baik dan memperbaiki kekurangan-kekurangan pada siklus I. Untuk meningkatkan kemampuan siswa dalam menulis puisi dan memperbaiki perilaku siswa kearah positif pada siklus II maka dilakukan perbaikan yaitu:

a. Memperbaiki rencana pelaksanaan pembelajaran, sehingga guru lebih memberikan motivasi pada siswa dengan membuat pembelajaran menjadi lebih santai sehingga siswa merasa senang untuk mengikuti pembelajaran.

b. Guru memotivasi dan membimbing siswa dalam menentukan objek atas apa yang dilihat dari alam sekitar tersebut agar mampu memilih kata yang tepat atas puisi yang telah ditentukan temanya serta mampu merangkai kata-kata dalam menulis puisi.

c. Guru menjelaskan kesalahankesalahan yang dilakukan siswa pada saat menulis puisi sehingga siswa lebih paham dan dapat memperbaiki kesalahannnya.

d. Memberi materi yang lebih lengkap lagi dibandingkan dengan siklus I.

e. Guru sering bertanya pendapat siswa dan memancing siswa agar semakin aktif saat pembelajaran.

Proses inti pembelajaran menulis puisi melalui media alam sekitar pada siklus II dimulai dengan guru memberikan penjelasan materi kepada siswa mengenai hakikat puisi, unsurunsur puisi, dan langkah-langkah menulis puisi. Pada tahap ini semua siswa terlihat sibuk menyimak dan memperhatikan penjelasan guru. Pada saat guru meminta siswa menutup buku dan memberikan pertanyaan tentang hakikat, unsur-unsur, dan langkah-langkah menulis puisi, siswa aktif menjawab pertanyaan dari guru. Suasana kelas menjadi kondusif dan aktif.

Tahap selanjutnya guru dan siswa bertanya jawab mengenai diksi dan tipografi dengan contoh puisi hasil karya siswa pada siklus I. Pada tahap ini banyak siswa menyadari puisi yang siswa tulis ada siklus I kurang memperhatikan aspek diksi. Setelah langkah tersebut langkah pembelajaran selanjutnya masih sama dengan siklus I yaitu guru meminta siswa untuk berkelompok kemudian guru meminta siswa membayangkan keindahan alam disekitar mereka, tiap kelompok membayangkan keindahan alam tersebut secara individu. Setiap siswa di dalam satu kelompok menulis apa saja yang ada dalam pikiran mereka kemudian didiskusikan bersama teman satu kelompok untuk merangkai ide-ide dari semua anggota kemudian secara bersama-sama disusun menjadi sebuah puisi yang indah.

Setelah selesai perwakilan kelompok maju dan membacakan hasil kerjanya. Meskipun siswa terkesan malu-malu saat membacakan puisi ke depan namun dorongan dari guru, siswa berani maju dan membacakan puisi hasil karyanya. Guru dan siswa lain memperhatikan dengan seksama kemudian guru meminta siswa lain memberikan apresiasi kepada kelompok yang maju atas hasil karyanya tersebut. Selanjutnya siswa menerima lembar kerja 2. Di dalam lembar kerja 2, guru meminta siswa menulis puisi secara individu dan kemudian dikumpulkan dalam waktu yang sudah ditentukan.

Pada hasil penelitian siklus II akan dibahas hasil tes dan non tes. Data tes diperoleh dari hasil kemampuan menulis puisi melalui media alam sekiatar. Data non tes diperoleh dari hasil observasi, jurnal, dan wawancara.

\section{a. Hasil Tes Siklus II}


Hasil tes menulis puisi pada siklus II merupakan data kedua meulis puisi melalui media alam sekiatar yang disertai upaya perbaikan dari hasil tes siklus I. Kriteria penilaian kemampuan menulis puisi pada siklus II ini masih sama dengan siklus I yang meliputi empat aspek penilaian, yaitu: (1) judul, (2) diksi, (3) kesesuaian isi dengan tema, dan (4) tipografi.

Tabel 4.4

Nilai yang diperoleh Siswa Kelas XII TKJ I dalam Menulis Puisi Melalui Media Alam Sekitar pada Siklus II

\begin{tabular}{|c|c|c|c|c|c|c|c|}
\hline \multirow[t]{2}{*}{ No } & \multirow{2}{*}{$\begin{array}{l}\text { Nama } \\
\text { Siswa }\end{array}$} & \multicolumn{4}{|c|}{ Aspek Penilaian } & \multirow{2}{*}{$\begin{array}{c}\text { Nilai } \\
\text { Siswa }\end{array}$} & \multirow{2}{*}{$\begin{array}{c}\text { Kategori } \\
\text { Nilai }\end{array}$} \\
\hline & & Judul & $\begin{array}{c}\text { Kesesuaian } \\
\text { Isi dengan } \\
\text { Tema }\end{array}$ & Diksi & Tipografi & & \\
\hline 1 & $\begin{array}{l}\text { Anggi } \\
\text { Sastrawati }\end{array}$ & 18 & 24 & 24 & 20 & 86 & Baik \\
\hline 2 & Hardiyanty & 18 & 18 & 32 & 20 & 88 & Baik \\
\hline 3 & Irmayanti & 24 & 18 & 32 & 20 & 94 & $\begin{array}{c}\text { Sangat } \\
\text { Baik }\end{array}$ \\
\hline 4 & $\begin{array}{l}\text { Nur Alifka } \\
\text { Kadir }\end{array}$ & 18 & 18 & 24 & 20 & 80 & Baik \\
\hline 5 & Nur Fajri & 18 & 18 & 32 & 20 & 88 & Baik \\
\hline 6 & Rahmi & 24 & 24 & 24 & 15 & 87 & Baik \\
\hline 7 & Sari Nita & 18 & 18 & 24 & 20 & 80 & Baik \\
\hline 8 & Sudarmi & 18 & 24 & 24 & 20 & 86 & Baik \\
\hline 9 & Sunarti M & 24 & 24 & 24 & 20 & 92 & $\begin{array}{l}\text { Sangat } \\
\text { Baik }\end{array}$ \\
\hline 10 & Suriyanti & 24 & 24 & 24 & 20 & 92 & $\begin{array}{l}\text { Sangat } \\
\text { Baik }\end{array}$ \\
\hline 11 & Teti Armita & 18 & 18 & 32 & 20 & 88 & Baik \\
\hline 12 & $\begin{array}{l}\text { Yola Indah } \\
\text { Pratiwi }\end{array}$ & 24 & 24 & 32 & 20 & 100 & $\begin{array}{l}\text { Sangat } \\
\text { Baik }\end{array}$ \\
\hline 13 & Yunita & 24 & 24 & 24 & 20 & 92 & $\begin{array}{c}\text { Sangat } \\
\text { Baik }\end{array}$ \\
\hline 14 & $\begin{array}{l}\text { Aan } \\
\text { Kurniadi }\end{array}$ & 24 & 24 & 24 & 20 & 92 & $\begin{array}{c}\text { Sangat } \\
\text { Baik }\end{array}$ \\
\hline 15 & Muh Danial & 24 & 18 & 24 & 20 & 86 & Baik \\
\hline 16 & Suharmin & 24 & 24 & 32 & 20 & 100 & $\begin{array}{l}\text { Sangat } \\
\text { Baik }\end{array}$ \\
\hline 17 & Yulianto & 24 & 18 & 32 & 15 & 89 & Baik \\
\hline 18 & Zulkifli & 24 & 24 & 32 & 20 & 100 & $\begin{array}{l}\text { Sangat } \\
\text { Baik }\end{array}$ \\
\hline
\end{tabular}




\begin{tabular}{llcccccc}
\hline 19 & $\begin{array}{l}\text { Dadang } \\
\text { Alfian }\end{array}$ & 24 & 24 & 32 & 20 & 100 & $\begin{array}{c}\text { Sangat } \\
\text { Baik }\end{array}$ \\
\hline 20 & $\begin{array}{l}\text { Reski Anria } \\
\text { Nasir }\end{array}$ & 24 & 24 & 24 & 15 & 87 & Baik \\
\hline 21 & Ismail & 24 & 24 & 24 & 20 & 92 & $\begin{array}{c}\text { Sangat } \\
\text { Baik }\end{array}$ \\
\hline Jumlah & $\mathbf{4 6 2}$ & $\mathbf{4 5 6}$ & $\mathbf{5 7 6}$ & $\mathbf{4 0 5}$ & $\mathbf{1 . 8 9 9}$ & \\
\hline Rata-rata & $\mathbf{2 2}$ & $\mathbf{2 1 , 7 1}$ & $\mathbf{2 7 , 4}$ & $\mathbf{1 9 , 2 8}$ & $\mathbf{9 0 , 4 3}$ & $\begin{array}{l}\text { Sangat } \\
\text { Baik }\end{array}$ \\
\hline
\end{tabular}

Untuk lebih jelasnya, nilai yang diperoleh siswa dalam menulis puisi melalui media alam sekitar pada siklus II adalah sebagai berikut:

Tabel 4.5

Hasil Tes Menulis Puisi Siswa Kelas XII TKJ I pada Siklus II

\begin{tabular}{|c|c|c|c|c|c|c|}
\hline No & Kategori & Nilai & Frekuensi & Jumlah Nilai & $\%$ & $\begin{array}{c}\text { Rata- } \\
\text { rata }\end{array}$ \\
\hline 1 & Sangat Baik & $90-100$ & 10 & 954 & 47,62 & \multirow{4}{*}{90,43} \\
\hline 2 & Baik & $70-89$ & 11 & 945 & 52,38 & \\
\hline 3 & Cukup & $50-69$ & 0 & 0 & 0 & \\
\hline 4 & Kurang & $0-49$ & 0 & 0 & 0 & \\
\hline & Jumlah & & 21 & 1.899 & 100 & \\
\hline
\end{tabular}

Sumber: Data diolah

Berdasarkan pada tabel 4.5 mengenai hasil tes menulis puisi siswa kelas XII TKJ I pada siklus II dapat dilihat bahwa dari total 21 siswa pada kelas XII TKJ I sebanyak 10 siswa atau sekitar 47,62\% yang mendapatkan nilai dalam kategori sangat baik. Siswa yang mendapatkan nilai dalam kategori baik sebanyak 11 siswa atau sekitar 52,38\% dan tidak ada siswa yang mendapatkan nilai dalam kategori cukup atau kurang. Hasil keseluruhan dari keempat aspek tersebut yaitu rata-rata 90,43. Secara umum telah mencapai ketuntasan ratarata kelas.

\section{b. Hasil Non Tes pada Siklus II}

Pada siklus II, data non tes diperoleh dari hasil observasi, jurnal, dan

wawancara. Hasil non tes selengkapnya akan dijelaskan pada uraian berikut ini:

\section{1) Hasil Observasi pada Siklus II}

Observasi dilakukan selama proses pembelajaran menulis puisi. Pengambilan data ini dilakukan dengan tujuan untuk mengetahui respon siswa melalui perilaku mereka selama pembelajaran menulis puisi melalui media alam sekitar. Observasi dilakukan oleh peneliti dan dibantu oleh satu seorang rekan peneliti. Berdasarkan hasil pengamatan atau observasi peneliti pada saat pembelajaran, secara keseluruhan perilaku siswa dalam pembelajaran menulis puisi sudah baik. Hal tersebut dapat dilihat dari tabel 4.6 berikut ini.

Tabel 4.6

Hasil Observasi Siswa pada Siklus II 


\begin{tabular}{llcc}
\hline a. Siswa mendengarkan penjelasan guru dengan penuh perhatian & 21 & 100 \\
b. Siswa aktif mencatat penjelasan guru & 21 & 100 \\
c. Siswa dapat bekerja sama dengan temannya & 20 & 95,23 \\
d. Siswa aktif bertanya kepada guru & 20 & 95,23 \\
e. Siswa aktif menjawab pertanyaan atau memberikan tanggapan & 19 & 90,47 \\
f. Siswa bersungguh-sungguh dalam mengerjakan tugas & 21 & 100
\end{tabular}

Pada siklus I ada beberapa siswa yang tidak memperhatikan penjelasan guru namun berdasarkan data siklus II pada tabel 4.6 di atas dapat diketahui bahwa seluruh siswa atau $100 \%$ siswa mendengarkan penjelasan guru dengan penuh perhatian pada saat pembelajaran menulis puisi, aktif mencatat penjelasan guru dan bersungguh-sungguh dalam mengerjakan tugas. Siswa yang dapat bekerja sama dengan temannya dan aktif bertanya kepada guru sebanyak 20 siswa atau sekitar $95,23 \%$ dan siswa yang aktif menjawab pertanyaan atau memberikan tanggapan sebanyak 19 siswa atau sekitar 90,47 .

\section{2) Hasil Jurnal pada Siklus II}

Jurnal yang digunakan pada tindakan siklus II sama seperti pada siklus I yaitu ini ada dua macam, yaitu jurnal siswa dan jurnal guru. Kedua hasil jurnal dalam tindakan siklus II diuraikan sebagai berikut.

\section{a) Jurnal Siswa pada Siklus II}

Pengisian jurnal dilakukan oleh semua siswa kelas XII TKJ I SMK Negeri 7 Takalar. Jurnal tersebut diisi pada akhir pembelajaran menulis puisi. Tujuan dari pengisian jurnal siswa adalah untuk mengetahui respon, pesan maupun kesan siswa terhadap pembelajaran menulis puisi melalui media alam sekitar.

Hal-hal yang diungkap dalam jurnal siswa siklus II sama dengan siklus I meliputi (1) perasaan siswa selama mengikuti pembelajaran menulis puisi melalui media alam sekitar, (2) kesulitan yang dialami siswa selama mengikuti pembelajaran menulis puisi melalui media alam sekitar, (3) pesan dan kesan siswa setelah mengikuti pembelajaran menulis puisi melalui media alam sekitar, (4) tanggapan mengenai media yang digunakan dalam pembelajaran menulis puisi melalui alam sekitar, dan (5) suasana kelas saat pembelajaran pembelajaran menulis puisi melalui media alam sekitar.

Dari hasil jurnal siklus II dapat diketahui bahwa 20 siswa atau 95,23\% menganggap langkah menulis puisi yang diajarkan guru membuat siswa semakin mudah menulis puisi. Siswa tertarik dan antusias pada saat kegiatan pembelajaran menulis puisi.

Menurut sebagian besar siswa penerapan media tersebut melatih mereka untuk berfikir secara individu meskipun dalam kondisi berkelompok. Siswa dapat berlatih apa artinya bekerja sama dengan teman satu kelompok dan saling memberi tahu yang tidak tahu menjadi tahu. Selain itu, dengan adanya media alam sekitar mereka lebih mudah memahami pembelajaran, siswa juga dapat belajar membuat puisi yang baik.

Menurut siswa penggunaan media alam sekitar juga lebih menyenangkan dan mempermudah dalam pencarian ide karena modern berbeda dengan kegiatan pembelajaran yang biasanya. Pada siklus I, ada siswa yang masih mengalami kesulitan dalam menentukan judul yang 
menarik, serta merangkai kata-kata menjadi sebuah puisi. Namun pada siklus II, siswa mulai bisa merangkaikan katakata dengan mudah, kesulitan-kesulitan yang ada pada siklus I bisa diatasi oleh guru dan siswa menjadi mengerti dan memahami pembelajaran tersebut.

Dari data jurnal siswa pada siklus II dapat disimpulkan bahwa sebagian besar siswa antusias dan senang mengikuti pembelajaran menulis puisi melalui media alam sekitar dibandingkan pada siklus I.

\section{b) Jurnal Guru pada Siklus II}

Jurnal guru pada siklus II sama seperti pada siklus I berisi seluruh kejadian yang dilihat dan dirasakan oleh guru selama proses pembelajaran berlangsung, jurnal ini diisi oleh guru yang menyampaikan materi pelajaran, dalam hal ini adalah peneliti sendiri. Halhal yang terdapat dalam jurnal guru yaitu: (1) bagaimana tanggapan siswa terhadap materi pembelajaran menulis puisi melalui media alam sekitar, (2) bagaimana tanggapan siswa terhadap pembelajaran menulis puisi melalui media alam sekitar, (3) bagaimana tanggapan siswa terhadap media yang digunakan dalam pembelajaran menulis puisi melalui media alam sekitar, (4) bagaimana tanggapan siswa terhadap media yang digunakan dalam pembelajaran menulis puisi melalui media alam sekitar, dan (5) bagaimana situasi dan suasana kelas saat berlangsungnya pembelajaran menulis puisi melalui media alam sekitar.

Berdasarkan hasil jurnal guru pada siklus II jauh lebih baik dibandingkan pembelajaran pada siklus I, sehingga dapat disimpulkan bahwa pembelajaran menulis puisi melalui media alam sekitar berjalan cukup baik dan lancar. Berdasarkan pengamatan guru selama proses pembelajaran, sebagian besar siswa sudah lebih baik memahami materi yang disampaikan oleh guru. Dengan adanya media yang diterapkan oleh guru siswa lebih bersemangat dalam belajar.

\section{c) Hasil Wawancara Siswa pada Siklus II}

Kegiatan wawancara dilakukan setelah selesai pembelajaran pada siklus II. Sasaran wawancara difokuskan pada tiga siswa, yaitu satu siswa yang mendapat nilai tertinggi, satu siswa yang mendapat nilai sedang/cukup, dan satu siswa yang mendapat nilai rendah/kurang. Tujuan peneliti melakukan wawancara pada siklus II ini adalah untuk membandingkan pembelajaran siklus I dan siklus II serta untuk mengetahui tanggapan atau sikap siswa terhadap pembelajaran menulis puisi melalui media alam sekitar.

Wawancara ini terdiri atas delapan pertanyaan, yaitu: (1) apakah siswa tertarik dengan pembelajaran menulis puisi, (2) bagimana suasana pembelajaran menulis puisi melalui media alam sekitar, (3) apakah siswa memahami penjelasan guru dalam pembelajaran menulis puisi, (4) bagaimana penjelasan guru dalam pembelajaran menulis puisi, (5) bagaimana pendapatmu terhadap media yang digunakan dalam pembelajaran menulis puisi, (6) kesulitan apa yang kamu hadapi selama kegiatan pembelajaran menulis puisi tadi, dan (7) bagaimana pendapatmu tentang kegiatan pembelajaran menulis puisi melalui media alam sekitar.

Berdasarkan wawancara yang dilakukan terhadap tiga siswa tersebut pada siklus II dapat disimpulkan bahwa secara keseluruhan siswa sangat senang dan tertarik dengan pembelajaran menulis puisi. Siswa yang mendapat nilai tinggi mengungkapkan bahwa dia sangat bersemangat karena menjadi lebih memahami dan mengerti dalam menulis 
puisi melalui media alam sekitar. Sedangkan siswa yang mendapat nilai sedang mengungkapkan bahwa dia sangat senang belajar menulis puisi dikarenakan penjelasan guru yang mudah diterima dan dipahami. Dan menurut siswa yang mendapat nilai rendah juga mengungkapkan awalnya kurang memahami sekarang sudah memahami pembelajaran menulis puisi melalui media.

Pada siklus II secara keseluruhan siswa menjadi lebih mengerti tentang pembelajaran menulis puisi melalui media alam sekitar dan merasa terbantu karena dapat mengetahui cara membuat puisi dengan mudah dan benar karena medianya sangat bagus. Selain itu, menurut siswa penyampaian materi dari guru jelas dan mudah dipahami. Mereka juga merasa pembelajarannya terkesan santai tapi tetap serius sehingga membuat belajar menyenangkan.

\section{3) Refleksi Siklus II}

Berdasarkan hasil kemampuan menulis puisi pada siklus II, dapat dikatakan bahwa kemampuan menulis puisi siswa kelas XII TKJ I SMK Negeri 7 Takalar mengalami peningkatan dari siklus I. Kemampuan menulis puisi pada siklus II mencapai rata-rata 90,43 atau berkategori sangat baik. Hasil tersebut sudah mencapai target yang diharapkan yaitu 75,00 .

Pada siklus II ini siswa sudah dapat menulis puisi dengan memperhatikan aspek-aspek penulisan puisi. Siswa sudah mampu dalam mengungkapkan apa yang mereka rasakan dan mereka amati ke dalam sebuah puisi, dan mereka tidak lagi merasakan kesulitan dalam menuangkan ide dan merangkaikan katakata dengan media alam sekitar.

Pada tahap observasi pada siklus II, terlihat tidak ada siswa yang melakukan perilaku negatif. Siswa mengikuti pembelajaran menulis puisi dari awal hingga akhir dengan sikap yang baik. Suasana terlihat kondusif dan menyenangkan. Hal ini dibuktikan melalui observasi dengan adanya peningkatan hasil persentase perilaku positif siswa pada hasil observasi siklus II.

Pada kegiatan pengisian jurnal, terlihat sekali perubahan sikap pada siswa. Siswa yang pada siklus I mengisi jurnal dengan tidak serius, pada siklus II sudah menunjukkan adanya keseriusan pada siswa. Siswa terlihat antusias terhadap pembelajaran yang dilakukan oleh guru. Mereka mengungkapkan bahwa pembelajaran yang diterapkan oleh guru sangat membuat mereka senang dan tidak membosankan. Hal ini terbukti adanya perubahan perilaku siswa yang positif.

\section{SIMPULAN DAN SARAN}

Berdasarkan rumusan masalah, maka hasil penelitian ini dapat disimpulkan sebagai berikut:

1. Kemampuan menulis puisi siswa kelas XII TKJ I SMK Negeri 7 Takalar setelah mengikuti pembelajaran menulis puisi melalui media alam sekitar mengalami peningkatan. Peningkatan ini terlihat dari perubahan nilai rata-rata dari siklus I ke siklus II. Pada siklus I diperoleh hasil rata-rata kelas sebesar 58,28. Pada siklus II diperoleh hasil rata-rata sebesar 90,43. Hal ini menunjukkan peningkatan dari siklus I ke siklus II sebesar $32,15 \%$.

2. Pada siklus I siswa belum sepenuhnya memahami dalam menulis puisi, siswa masih kesulitan dalam menulis puisi melalui media alam sekitar. Siswa masih merasa kesulitan dalam memilih kata dan merangkai kata-kata dalam menulis puisi. Pada siklus II, siswa 
sepenuhnya mampu menulis puisi dengan baik. Hal ini terbukti adanya peningkatan dalam pemilihan kata dan dalam merangkai kata-kata dalam menulis puisi, serta kesalahankesalahan yang terjadi pada siklus I dapat diperbaiki di siklus II. Puisi yang dihasilkan lebih bagus dan menarik. Selain itu, siswa lebih antusias dan serius dalam mengikuti pembelajaran menulis puisi.

3. Analisis data non tes melalui observasi, wawancara, dan jurnal menunjukan bahwa siswa kelas XII TKJ I SMK Negeri 7 Takalar memberikan respon positif setelah pembelajaran menulis puisi melalui media alam sekitar. Mereka lebih pandai dalam menulis puisi dikarenakan siswa lebih mudah dalam menuangkan ide. Dilihat dari perilaku siswa kelas XII TKJ I SMK Negeri 7 Takalar dalam mengikuti pembelajaran menulis puisi melalui media alam sekitar mengalami perubahan. Perubahan tersebut yaitu dari perilaku negatif menjadi perilaku positif.

Berdasarkan simpulan di atas, maka disarankan hal-hal sebagai berikut:

1. Bagi Guru

Guru dapat mengenalkan media alam sekitar kepada rekan sejawatnya, sehingga guru yang lain juga dapat mempraktikkan media alam sekitar dalam pembelajaran menulis puisi.

2. Bagi Siswa

Siswa sebaiknya lebih kritis dan terbuka terhadap hal-hal baru yang mereka peroleh sehingga mampu menunjang proses dan hasil belajar mereka di sekolah.

3. Bagi Sekolah

Pihak sekolah sebaiknya semakin giat memberikan motivasi kepada guru untuk terus mengembangkan diri dengan melakukan banyak penelitian. Hal ini bertujuan untuk meningkatkan kualitas guru dan keterampilan mengajar guru.

\section{DAFTAR PUSTAKA}

Aminuddin. 2002. Apresiasi Karya Sastra. Bandung: Algesindo Sinar Baru.

Andayani. 2008. Pembelajaran dan Apresiasi Sastra Berbasis Quantum Learning

Disekolah Dasar. Solo : Sebelas Maret University press.

Arikunto, Suharsimi. 2007. Penelitian Tindakan Kelas. Jakarta : Bumi Aksara.

Arsyad, A. 2002. Media Pembelajaran. Edisi 1. Jakarta: PT. Raja Grafindo Kitab Lengkap Puisi, Prosa dan Pantun

Lama Persada.

Azzani. Jamil. 2009. 7 Kedahsyatan Menulis dalam http://jamil.niriah.com. (Diakses Tanggal 10 Mei 2015)

Hamalik,1994. Media Pendidikan, Cetakan ke 27. Bandung: Penerbit PT. Citra

Aditya Bakti.

Pradopo, Djoko, Rahmat. 1997. Pengkajian Puisi. Yogyakarta: Gajah Mada Universitas Press.

Prasetyo. 2007. Jurnal Pendidikan Inovatif. Jakarta: Bumi Aksara.

Semi, Atar. 1990. Menulis Efektif. Padang: Angkasa Raya.

Sudjana. 1996. Fungsi dan Pengembangan Media Pembelajaran. Jakarta: 
Universitas Terbuka dan Pusat Antar Universitas.

Supriyadi. 1994. Pendidikan Bahasa Indonesia 2. Jakarta. Depdikbud.

Tarigan. 1993. Menulis Sebagai Suatu Keterampilan Berbahasa. Bandung Angkasa.

Waluyo, Herman, J. 2007. Teori dan Apresiasi Puisi. Surakarta: Universitas Sebelas Maret Press.

Wahyuni, Ristri. 2014. Kitab Lengkap Puisi, Prosa dan Pantun Lama. Jogyakarta:

Saufa. 